\title{
2009 impact factor: a new reality for Jornal de Pediatria
}

\author{
Renato S. Procianoy*
}

$E_{\text {diting a scientific medical journal is not an easy }}$ task. The expectations of two different types of customers (readers and authors) need to be fulfilled, and they often have mismatched interests and goals. Readers, either clinical practitioners or investigators, want to read articles that can be useful to them. On the other hand, authors want their papers to be published in journals with high visibility and scientific recognition, which makes it possible to widely disseminate their studies.

Having this in view, how can the significance of a scientific medical journal be measured in the current context? What should be considered important? Some possible answers to these questions include the number of copies in each print run, the number of online visits, the impact of the articles published in that journal on the daily medical practice, or the number of times the articles published in that journal are cited in other articles. It seems quite reasonable to believe that all these criteria are important. However, some difficulties are associated with their use. The number of copies in each print run is a measure that has been abandoned. Many journals are only available online, and the number of printed journals tends to decrease because of the high costs of printing and distribution and the environmental issue. Counting online visits is difficult, and the data obtained are not always reliable. Moreover, readers who visit online journals form a very heterogeneous group and sometimes they are not the main target audience of the authors publishing in a given journal. The impact on the daily practice of published articles cannot be measured and often does not occur immediately after publication. Therefore, within the current context, the only reliable measure available with short-term results is the number of citations of articles published in a given journal by other scientific papers. This is called impact factor.

Impact factor is defined as the ratio between the number of citations in a given year of articles published in a journal during the preceding 2 years and the total number of articles published in those 2 years in the same journal. Therefore, the analysis of the impact factor allows to assess the importance of the articles published in a journal in a period of 2 years after its publication. In spite of being much criticized, the impact factor continues to be widely used to evaluate scientific journals ${ }^{1}$ : the higher the impact factor, the higher the journal's prestige in the international scientific community.

In 2007, when I announced that Jornal de Pediatria was being included in the database of Thomson Reuters (ISI) and that it would have its impact factor measured, I also pointed out that the impact factor of Jornal de Pediatria would enable the evaluation of the significance of Brazilian scientific production in the international scene. ${ }^{2}$

Impact factors are published in the Journal Citation Reports (JCR), which includes more than 10,000 journals of science and social sciences. There are 17 Brazilian journals in the clinical medical area, and in the pediatric area, 94 journals from at least 16 different countries are indexed. Jornal de Pediatria is the only Latin American pediatric journal included in the database.

The first impact factor for Jornal de Pediatria (2009 impact factor), disclosed in late June 2010 , is 1.382 , which ranks our journal 48th out of all international pediatric journals and fourth out of all Brazilian medical journals. This confirms the strength of the Brazilian medical research, particularly in the pediatric field, as previously reported. ${ }^{3}$

\footnotetext{
* Professor titular, Pediatria, Universidade Federal do Rio Grande do Sul (UFRGS), Porto Alegre, RS, Brazil. Chefe, Serviço de Neonatologia, Hospital de Clínicas de Porto Alegre (HCPA), UFRGS, Porto Alegre, RS, Brazil. Editor-Chefe, Jornal de Pediatria.

No conflicts of interest declared concerning the publication of this editorial.

Suggested citation: Procianoy RS. 2009 impact factor: a new reality for Jornal de Pediatria. J Pediatr (Rio J). 2010;86(4):255-256. doi:10.2223/JPED.2023
} 
One of the reasons for the success of Jornal de Pediatria is the diversity of the articles published. The topics addressed in our articles range from primary care issues, such as breastfeeding, to translational research, as well as observational studies and clinical randomized trials. ${ }^{4-7}$ Our only commitment is to guarantee the scientific quality of the manuscripts accepted for publication. We have achieved the objective set out when I was nominated as editor-inchief of Jornal de Pediatria, in March 2002. At that time, we decided that Jornal de Pediatria should bridge the gap between basic research and clinical practice in pediatrics, always contributing to spread new knowledge and trying to keep our readers updated about the most recent scientific findings in the field. ${ }^{8}$

Such excellent result is a consequence of the hard work and effort of many people: the associate and executives editors, who have actively participated in the project over the years; the Editorial Board, which has always replied to our requests promptly; the presidents of the Brazilian Society of Pediatrics, Lincoln Marcelo Silveira Freire, Dioclécio Campos Jr., and Eduardo da Silva Vaz, who have always supported our decisions; the board of the Brazilian Society of Pediatrics, which has provided the necessary support for the journal's development; the independent reviewers, who were always ready to collaborate; and, in particular, the investigators, who submitted excellent articles for publication.

In sum, I hope that this is just the beginning of the journey for the scientific growth and international recognition of Jornal de Pediatria.
References

1. Garfield E. The history and meaning of the journal impact factor. JAMA. 2006;295:90-3.

2. Procianoy RS. The journal impact factor today. J Pediatr (Rio J). 2007;83:487.

3. Piccoli N, Procianoy RS. Brazilian scientific journals: an overview. Eur Sci Edit 2007;33:73-4.

4. Parizoto GM, Parada CM, Venâncio SI, Carvalhaes MA. Trends and patterns of exclusive breastfeeding for under-6-month-old children. J Pediatr (Rio J). 2009;85:201-8.

5. Passoni CR, Coelho CA. Ascorbic acid supplementation has a cytoprotective effect on secondary biliary cirrhosis: experimental study in young rats. J Pediatr (Rio J). 2008;84:522-8.

6. Almeida MF, Guinsburg R, Martinez FE, Procianoy RS, Leone CR, Marba ST, et al. Perinatal factors associated with early deaths of preterm infants born in Brazilian Network on Neonatal Research centers. J Pediatr (Rio J). 2008;84:300-7.

7. Moraes MA, Bonatto RC, Carpi MF, Ricchetti SM, Padovani CR, Fioretto JR. Comparison between intermittent mandatory ventilation and synchronized intermittent mandatory ventilation with pressure support in children. J Pediatr (Rio J). 2009;85:15-20.

8. Procianoy RS. Commitment to quality. J Pediatr (Rio J). $2002 ; 78: 83$

Correspondence:

Renato S. Procianoy

Rua Silva Jardim, 1155/701

CEP 90450-071 - Porto Alegre, RS - Brazil

E-mail: renatosp@terra.com.br

\title{
Toward high quality medical care for sickle cell disease: are we there yet?
}

\author{
Jane Hankins*
}

Sickle cell disease (SCD), one of the most common single gene disorders in the world, affects approximately 280,000 live births per year worldwide; SCD and thalassemia syndromes together account for $3.4 \%$ of all deaths of children younger than 5 years. ${ }^{1}$ Infants with SCD are particularly at risk of premature mortality from SCD because of the early loss of the filtrative function of the spleen. ${ }^{2,3}$ This places these vulnerable infants at a high risk of invasive infection by encapsulated organisms, especially pneumococcus. In addition, splenic sequestration is an important SCD-related complication that, if not recognized and treated early in its course, can lead to circulatory collapse and death. ${ }^{4}$

Despite the increased risk of fatal complications in early life, mortality rates of patients with SCD have significantly

* MD, MS. Assistant member, Department of Hematology, St. Jude Children's Research Hospital, Memphis, TN, USA.

No conflicts of interest declared concerning the publication of this editorial.

Suggested citation: Hankins J. Toward high quality medical care for sickle cell disease: are we there yet? J Pediatr (Rio J). 2010;86(4):256-258. doi:10.2223/JPED.2021 